\title{
Money and Currency
}

\author{
Gaspar Feliu \\ Translated by Ramon Pujol Gorné
}

The purpose of my contribution is to study different aspects of medieval money in its two forms, as a unit of value and as a means of payment. After a general introduction about the characteristics of medieval money, I will examine the types of currency, including non-monetary forms of payment, the causes that explain the introduction and the use of every means of payment, and indicate very briefly the problems generated by the relationship between the different types of currency.

\section{Definition and Kinds of Moneys}

Money is in essence a concept, an abstract unit of value that is used as a universal equivalent to compare any good or service with all others. The concept of money from a logical point of view must precede any physical monetary reality, but to be fully effective, to be able to act, money as a concept must be brought to life through its materialization in an object that the community accepts as money. Under this double form, money meets the three functions that are considered basic for its characterization and definition: to be a unit of account, a means of exchange (currency), and a store of value. I think that to these should be added a fourth function: to be an instrument of business through credit. ${ }^{1}$

The objects used as currency have varied throughout space and time, but they can be reduced to two classes: goods that have intrinsic value (real currency) and symbols (shells, stones, printed paper, pieces of metal), whose intrinsic value is lower than their value as currency, so they receive the name of fiduciary money.

Although as we will see there are other types of effective currency, in the Middle Ages its most common form was coined currency. It could be issued

1 Munro, "Introduction", p. 1, points out this function ("Standard of deferred payments") but does not refer to the possibility of profit, which is synonymous with credit. 
either by the local authority or an external one; it could be current or old; it could consist of specimens in good or bad condition and might even extend to counterfeit or false money (as long as the deception was not discovered) or pieces which were worn or damaged. In addition, the concept of money could take the form of money of account, with no physical existence; in such cases it was only a unit of value, useful for counting or accounting but not used directly as a medium of exchange or saving.

\section{General Characteristics of Medieval Money}

The main features to keep in mind to understand the functioning and the evolution of medieval currency are: ${ }^{2}$

1. The noble metals (silver and gold), the basis of the medieval monetary systems, were almost always insufficient to meet the needs of the demand for currency.

2. There were large differences in the availability and the temporal, spatial, and social distribution of the currency. ${ }^{3}$

3. The value of each coin depended on the sort of metal used and the known parameters of weight standard, number of coins struck, and fineness.

4. Each coin had three currency values - the intrinsic value of the metal coined; the legal value that was attributed by the issuing authority; and the market value - although as a general rule the three values differed little. The legal value was almost always higher than the intrinsic value, due to the costs of coining ("brassage") and also to the fee that the minting authority levied on coins for its own benefit ("seigniorage"). ${ }^{4}$ Only when the legal value significantly exceeded the intrinsic value did a separate market value appear, which tended to reduce the difference between the other two. ${ }^{5}$

5. Coins circulated with few restrictions outside the territory of the issuing authority.

2 These features apply especially to minted coins; almost none of them is always and everywhere present, but all of them have broad spatial and temporal validity.

3 J. Day, "An outline of money", pp. 1-2.

4 In English this is usually called "seigniorage" or "gros seigniorage", the difference between the price of the metal and the legal price of currency. I follow the continental practice of distinguishing them because it helps to clarify understanding of the process.

5 The difference may come from a very high seigniorage or from a change in the price of metal on the market; Bloch, Esquisse d'une histoire monétaire, p. 9; and Munro, "Technology and economics", p. 19. 
6. The diversity of local and foreign coins circulating in a given territory explains the need for money of account.

\section{Medieval Means of Payment}

\section{Non-Monetary Exchanges}

Since the beginning of the 5 th century, the economy of Western Europe had entered a state of economic and monetary prostration, with limited exchanges and poor circulation of currency; ${ }^{6}$ however, the concepts of currency and price were always present, although at some times and places reduced to a minimum. ${ }^{7}$

Barter, which is considered the simplest form of exchange, appeared in the first centuries of the Middle Ages in marginal areas, ${ }^{8}$ but was clearly influenced by the notion of currency, as David Graeber argues that all exchange is ultimately barter. ${ }^{9}$ Often a good is exchanged for a jumble of miscellaneous commodities, which indicates an estimated value, next to a price valuation: "six measures of grain, bedding, a tunic or shirt, two rams, four cheeses". ${ }^{10}$ In fact, the words "sale" or "price" often appear in documents in which a benefit or good is exchanged for another benefit or good. ${ }^{11}$

The next step up from barter is payment through certain goods that function as standard currency in a certain society, without any mention of price. They are a partial monetary equivalent, even with a certain gradation according to the value of the goods being purchased, from an ox or a horse for large payments to a measure of wheat, a sheep, or a pound of wax for medium-sized payments, or a loaf of bread for small payments. ${ }^{12}$

However, the most common way of making non-cash payments was to set the price in currency and indicate the payment "in rem valentem" or in "res valentes", which may or may not be stated ("bove uno valente"). In this sense,

6 Cipolla, "Primitive money in primitive Europe", p. 7 .

7 Bloch, "Natural economy and money economy", p. 231; Cipolla, "Primitive money in primitive Europe", p. 12.

8 For the northwest Iberian Peninsula: Gautier-Dalché, "L'histoire monétaire de l'Espagne"; Davies, "Sale, price and valuation".

9 Graeber, Debt, p. 40.

10 Davies, "Sale, price and valuation", p. 159.

11 "Vindo vobis campo ... et ipsa area ... precium ... kavallo placibilie ... et duos boves placibiles", in a Catalan document from 817: Abadal, Catalunya Carolíngia, Vol. 3: Els comtats de Pallars i Ribagorça, doc. 3, pp. 281-82.

12 Cipolla, "Primitive money in primitive Europe", pp. 4-5. 
any property can be used as a means of payment. ${ }^{13}$ Sometimes a debtor had the choice of making a payment in currency or in a particular good, with expressions such as "quem habuero" ("whichever I might have"); the good had to be considered in this case as an acceptable equivalent. ${ }^{14}$ Payments in kind persisted for a long time, even in societies with a wide use of currency: in Catalonia, for example, during the 11th century payments in kind still accounted for 27 per cent among a sample of documents studied by Pierre Bonnassie. ${ }^{15}$ In fact, these percentages are surely underestimates: the mention of "in rem valentem" indicates a payment in specie, but expressing a price in currency does not rule out the payment being carried out in specie. ${ }^{16}$ Monetary quantification fulfilled the role of expressing value, not necessary as a means of payment.

\section{Object-Coins}

Until the end of 8th century there were coins but no monetary system: the scarce currency consisted mostly of later imperial gold coins (Constantinian solidi or aurei), usually very worn, and trientes, theoretically a third of the solidus, coined by barbarian monarchs, local authorities, and even private goldsmiths ${ }^{17}$ in limited accounts and very diverse emissions, ${ }^{18}$ in such a way that they cannot be considered units of value, but weights of noble metal. Coins and goods could be mingled in the same payment, regardless of whether the total amount to pay was indicated: the currency in this case was considered more as merchandise ${ }^{19}$ and the coins that were handed over surely did not constitute a fixed monetary value, but rather a weight in metal.

For high-value trade, people in the earlier Middle Ages turned to contemporary Byzantine or Muslim gold currency, of higher value and more reliable and stable. Only in the south of Italy and in the Iberian peninsula, territories

\footnotetext{
13 Gautier-Dalché, "L'histoire monétaire de l'Espagne", pp. 45-46.

14 For its use in legal codes, Bloch, Esquisse d'une histoire monétaire, pp. 27-28; generally, Cipolla, "Primitive money in primitive Europe", pp. 3-4 and 8.

15 Bonnassie, La Catalogne du milieu du Xe à la fin du XIe siècle, p. 906.

16 Cipolla, "Primitive money in primitive Europe", p. 6.

17 See Chapter 4 in this volume.

18 Bloch, Esquisse d'une histoire monétaire, p. 15; and W.R. Day, "Monetary reforms of Charlemagne", p. 34. Sánchez-Albornoz, Estampas de la vida en León, p. 61, shows that Roman denarii circulated in León, along with gallican solidi (from either Galicia or Gaul?) and simple scraps of silver.

19 Cipolla, "Primitive money in primitive Europe", p. 6. A document from the year 1102 of the monastery of La Grasse, in Languedoc, includes a payment of 15 pounds in silver, 40 shillings from Roussillon, a horse, and two young horses, to cite just one example; MagnouNortier and Magnou (eds.), Recueil des Chartes de l'Abbaye de la Grasse, doc. 170.
} 
more in contact with Byzantium or the Muslim world, did such coins circulate with some degree of normality. They would end up being imitated by local powers. ${ }^{20}$

The long persistence of non-monetary exchanges (although sometimes including a proportion of coins) is due to several factors:

1. The currency's scarcity, poor reliability and uneven distribution. ${ }^{21}$

2. The hoarding of existing coins and the preference for keeping noble metals in the form of objects (dishes, silverware, jugs, objects of worship) which provided pleasure or utility to their owners. ${ }^{22}$

3. The ease of using these objects as currency or converting them into means of payment.

4. The limitations of the market in a largely autarkic economy: lords received goods or services in exchange for their incomes, so the currency was only needed for the sporadic acquisition of luxury goods as well as bulk purchases, gifts, fines, rents, taxes (sometimes), and so on. ${ }^{23}$

\section{Non-Coined Currency}

Medieval currency was not always coined; there were also non-metallic coins. The main ones consisted of pieces of fabric with certain characteristics and of fixed size, used in Friesland; and pepper, documented as currency from the 1oth century to the 14th, usually in closed and sealed bags, which was an important part of the economy in Genoa. ${ }^{24}$ In both cases these "coins" coexisted in documents with specie payments and coined currency; they are considered an indicator of shortages and at the same time of the poor quality of the circulating currency. Uncoined pieces of metal ("bullion"), assessed by weight, also functioned as currency and were widely used in international trading. ${ }^{25}$ All of these were real currency: they had value as a commodity and can be

20 Duplessy, "La circulation des monnaies arabes"; and Grierson, "Carolingian Europe and the Arabs", pp. 1059-74.

21 H. Van Werveke, "Monnaie, lingots ou marchandises?", pp. 453-54.

22 Since the currency was only needed now and then, to keep it was a misuse of wealth; Van Werveke, "Monnaie, lingots ou marchandises?"; Bloch, "Natural economy and money economy", pp. 234-36.

23 "A monetary system cannot exist and cannot work if it is not supported by an efficient market." Cipolla, "Primitive money in primitive Europe", p. 10. Also Naismith, "Social significance".

24 Bloch, Esquisse d'une histoire monétaire, pp. 27-28.

25 Munro, "Introduction", p. 2. 
considered as "substitute coins", but in fact, most of the real coins circulating in the Middle Ages were metallic. In an economically sophisticated society, such as that of Genoa, uncoined money served primarily as a substitute currency in periods of monetary scarcity caused by taxes, rents, and especially the exportation of money to other markets (such as those in the east), in which demand was such that one could not sell as much as others wanted to buy.

\section{The Silver Penny}

After some earlier attempts in France, Frisia, and England, the Emperor Charlemagne introduced a monetary system based on the silver penny (also known as "denarius" or "denier"), which almost completely dominated the European monetary panorama from the 9th century to the middle of the $13^{\text {th. It re- }}$ mained for centuries the standard for European currency, ${ }^{26}$ and did not definitively disappear until 1972, with the introduction of the decimal system in the English currency. Its basis was a pound unit of weight from which 240 pieces of one penny (denarius) were obtained. ${ }^{27}$ Gold was at this time worth 12 times more than silver. The equivalent of 12 pennies was used as a multiple with the name of solidus (in memory of the old Roman coin) or shilling. ${ }^{28}$ This parity converted the shilling into the twentieth part of the pound, and the system was defined as a pound of 20 shillings and a shilling of 12 pennies. Only the penny was coined, however; the shilling and the pound were used only as accounting multiples or for enumerating large amounts. The fact that the base of the system was silver and not gold did not mean an economic setback; on the contrary, it underlined the passage from a coin to hoard to a coin for trade.

As a model, the Carolingian monetary system persisted for a long time; as a reality, it quickly became disorganized. The successors of Charlemagne issued pennies with various contents of silver and from the 1oth century many local powers (counts, bishops, etc.) coined pennies on their own. ${ }^{29}$ The trend was for the pennies to contain less and less silver, with large differences between

\footnotetext{
26 Bloch, Esquisse d'une histoire monétaire, pp. 22-23.

27 In reality, every pound produced more than 240 pennies to pay the mint cost ("brassage") and seigniorage. According to a document of Pippin the Short, Charlemagne's father, each pound was divided into 264 pennies, the excess being distributed equally between the officer of the mint and the monarch; Miskimin, "Two reforms of Charlemagne?", p. 47. "Denarius" is the origin of the abbreviation "d." formerly used for pence.

28 As Cipolla, "Ghost moneys", p. 40, notes, the shilling was the link between the past and the new system.

29 Bloch, Esquisse d'une histoire monétaire, p. 21; and Munro, "Introduction", pp. 4-5.
} 
mints, so that it was necessary to specify the origin of the pennies. ${ }^{30}$ When in the same place the difference between an issue and the previous one was too large, it was also distinguished with different denominations. In Catalonia, for example, the first mention of dinarios curribiles (current pennies), as opposed to the pennies of silver or of full weight, is from the year $991 .{ }^{31}$ Later, throughout the first half of the 11th century, there were several mentions of moneta nova (new money) and especially of moneta grossa (full money)..$^{32}$ As we shall see in due course, this monetary duality is at the root of money of account.

Except in England, the degradation of money was a general phenomenon: in 1250, the penny of the Republic of Venice contained only 5 per cent silver with respect to the initial penny, while the English penny maintained 98 per cent. ${ }^{33}$ There are four principal reasons that explain the debasement of the different pennies: wear of the circulating currency; shortage of silver relative to demand; crimes against the currency; and the need or ambition of the issuing authorities. ${ }^{34}$

However, stable currency was considered a benefit in itself, which led to the question of whether a ruler could legally change the currency and even whether a tax could be imposed in exchange for avoiding the change of currency during each reign. ${ }^{35}$ This is, however, an issue which I will only note in passing.

\section{Full Silver Coins}

The mixed effect of the reduction in value of the different pennies and of economic growth, together with the interconnection of trade in the Mediterranean,

30 In a document of the monastery of La Grasse appears the statement: "quadraginta solidos Ugonencos octonos de Carcassona et ... quadraginta solidos milgurienses et una libra de plata ad pensum de Narbona": Magnou-Nortier and Magnou, Recueil des Chartes de l'Abbaye de la Grasse, doc. 134 .

31 These coins would be new and would be called this, as opposed to the previous ones, which would continue circulating; Jarrett, "Currency change in pre-millennial Catalonia", pp. 226-8.

32 Bonnassie, La Catalogne du milieu du Xe siècle à la fin du XIe siècle, p. 387; "gross" refers to a coin, specifically one of full silver.

33 Cipolla, "Currency depreciation in medieval Europe", p. 422.

34 On these various points, Bloch, Esquisse d'une histoire monétaire, pp. 6o-70; Cipolla, "Currency depreciation in medieval Europe"; Day, "An outline of money", pp. 12-13; and Sargent and Velde, Big Problem, pp. 64-67.

35 Bisson, Conservation of Coinage; and Spufford, "Monetary practice and monetary theory", pp. 54-55. 
achieved what Marc Bloch called the great change of the 13th century: ${ }^{36}$ the appearance of full silver coins and, after half a century, of gold coins.

The new silver coins, called generically grossi, tended to reach back to the value of primitive money at each location. It was precisely in Venice, whose penny had suffered a further debasement, where the first silver grosso was coined in the year 1203; it was called a matapan and equated to 24 current pennies. ${ }^{37}$ The example was imitated first by cities throughout the north of Italy, which coined grossi of similar value, with different equivalences to the local penny, depending on the exact silver content. In the second half of the century almost all the powers of occidental Europe followed suit. ${ }^{38}$

Full silver coinage proved effective and was the first European currency suitable for international trade, but it also added another factor to the deterioration of the pennies. The grosso's silver content was fixed, as a general rule, as equivalent to the sum of the silver contained in the pennies that equated its value. But coining the pennies equivalent to a grosso was more expensive than coining a single grosso. ${ }^{39}$ For this reason, the operators of the mints tended to neglect the minting of pennies, ${ }^{40}$ which led to protests against the scarcity of "petty coins", increased wear on the ones which circulated, and the loss of value of the penny with respect to the grosso and also to the production of pennies with lower silver content (debasement). This vicious circle was very well described by Carlo Cipolla and by Thomas J. Sargent and François Velde (see also Figure 2.1). The penny became a fiduciary currency, a circumstance which had significant social implications. ${ }^{41}$

\section{Gold Coins and Monetary Systems}

Despite the importance of the grossi, a still greater monetary change was the minting of gold coins. Although in the middle of the 13th century Sicily and Castile had monetary systems based on gold, these were marginal economies,

\footnotetext{
36 Bloch, Esquisse d'une histoire monétaire, p. 11.

37 The matapan lined up with the English penny, since both contained 1.35 grams of pure silver: Cipolla, "Currency depreciation", p. 418.

38 Bloch, Esquisse d'une histoire monétaire, p. 26; Fournial, Histoire monétaire, pp. 78-80; and Spufford, Money and Its Use, pp. 404-6.

39 Day, "The problem of the standard", p. 75; Sargent and Velde, Big Problem, p. 52 also offers examples of the relative cost of minting different coins.

40 Usher, Early History of Deposit Banking, p. 198; and Munro, "Technology and economics", p. 19 .

41 Cipolla, "The big problem of the petty coins", pp. 27-37; and Sargent and Velde, Big Problem, p. 129. See also chapter 8 , this volume.
} 
VENICE, GROSSI FOR PICCOLO

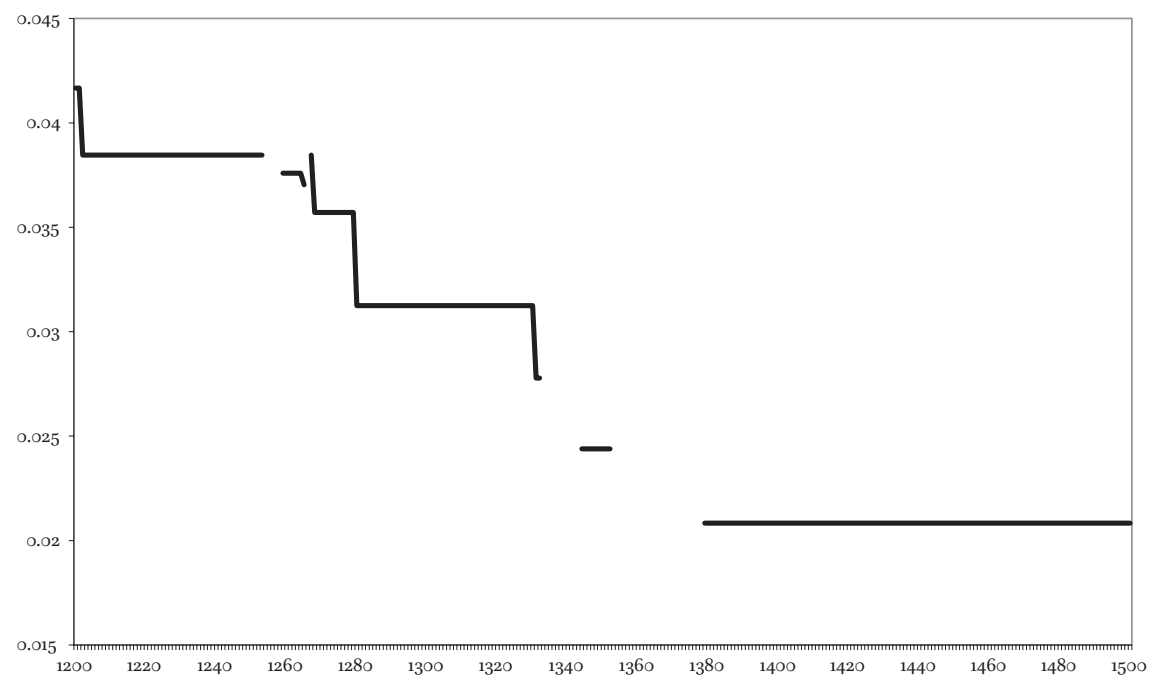

FIGURE 2.1 Valuation of piccolo relative to the grosso at Venice, 1200-150O.

ADAPTED BY THE AUTHOR FROM SPUFFORD, HANDBOOK OF MEDIEVAL EXCHANGE, P. 85.

which is why the introduction of the florin in Florence and the genovino in Genoa, minted from around the same time in 1252 , is often considered to be the beginning of "the return to gold" in the West. ${ }^{42}$ The first imitations in England (1257) and France (1266) were not successful. A new momentum came in the year 1285 with the introduction of the zecchino or Venetian ducat and, soon after, of the royal assis or French florin (1290). In the majority of European countries, the gold coin was an innovation of the 14th century.

The use of different coins for different purposes was well adapted to the economic and social situation of the time, but it was very difficult to manage. Although sometimes there has been discussion of medieval bimetallism, this was not a bimetallic system, which would have required a fixed exchange between silver and gold. ${ }^{43}$ Rather, there were three systems based on three different

42 Lopez, "Settecento anni fa"; and Lopez, "Back to gold". In reality, the grosso d'oro fino of Lucca preceded the florin and the genovino, but it was of short duration, so its primacy is irrelevant: Fournial, Histoire monétaire, p. 80.

43 Only in Florence was there an intention to create a bimetallic system, with a fixed relationship between the three currencies and in which the gold florin was equivalent to the pound and the florin of silver or grosso to the shilling - but the system foundered 


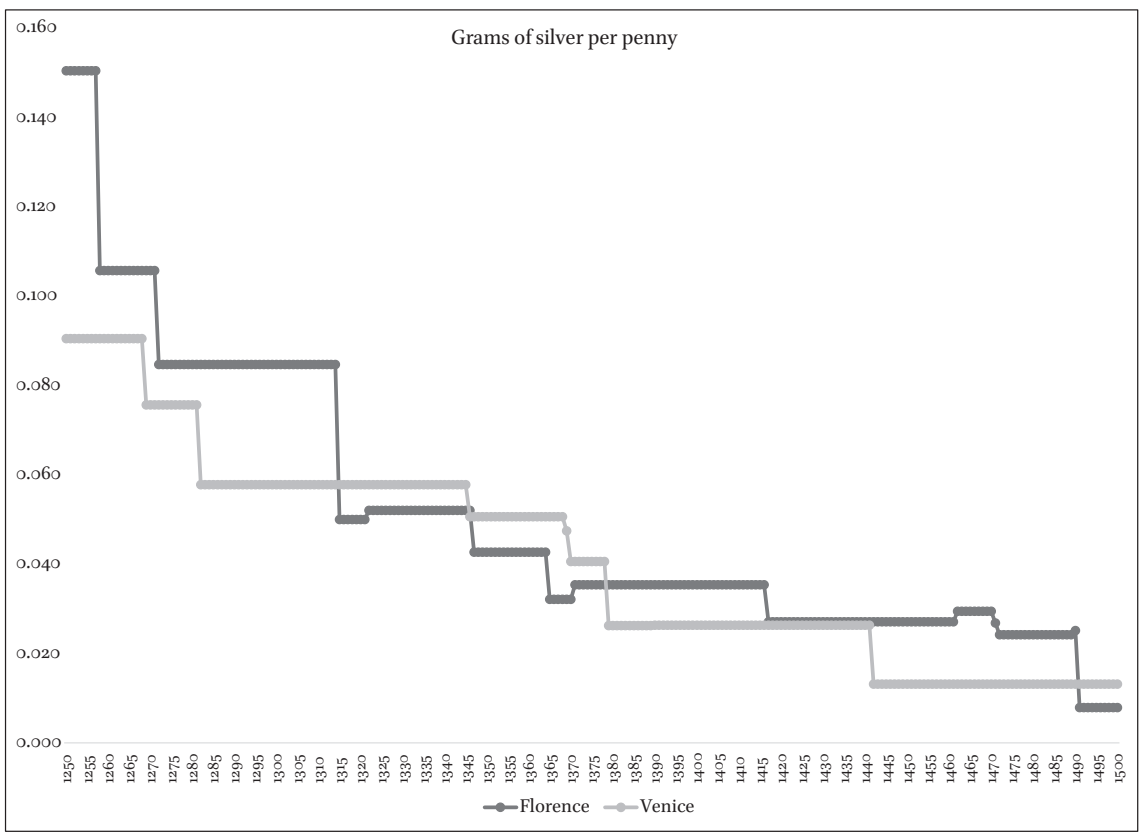

FIGURE 2.2 Grams of silver per penny at Florence and Venice.

ADAPTED BY THE AUTHOR FROM SPUFFORD, HANDBOOK OF MEDIEVAL

EXCHANGE, PP. 1-25 AND 81-84. ONLY THE FIRST MENTION OF EACH YEAR HAS BEEN RETAINED.

coins: the penny, the grosso (silver florin), and the gold florin, based on the necessary adjustment between them ${ }^{44}$ which meant a debasement of the penny in relation to the grosso and of the latter with regard to gold (see Figure 2.2).

\section{Fiduciary Money}

Fiduciary money is any which has a legal value higher than its intrinsic value. It can be purely fiduciary ("token money"), as with the currency of many primitive peoples or that of modern times, ${ }^{45}$ or partially fiduciary if the value

quickly. Usher, Early History of Deposit Banking, p. 202; Lopez, "Back to gold", p. 224; and Day, "Problem of the standard", pp. 69-72.

44 Bloch, Esquisse d'une histoire monétaire, p. 39.

45 For "primitive" peoples, see Einzig, Primitive money. The current currency became completely fiduciary with the abandonment of the gold parity of the US dollar in 1971. 
of the noble metal that each coin contains is lower than the legal value ("fiat money"). In medieval western Europe there were no token moneys, although (especially from the 13th century in the Mediterranean), there were numerous partially fiduciary coins, especially pennies with a sometimes-minimal content of silver. ${ }^{46}$ At some times and places there were also fiduciary grossi and even some fiduciary gold coins whose legal value was fixed above their intrinsic value. ${ }^{47}$

The principal cause for the appearance of fiduciary money was the manipulation of the coinage by the authorities, whether to increase the income from seigniorage or to avoid a scarcity of low-value coins, or indeed both at the same time. In fact, fiduciary money arose and expanded in urban economies whose general growth created a higher demand for money than the available stock of metal could fulfil. ${ }^{48}$ Faced with a shortage of real currency, the public accepted the fiduciary coins as a lesser evil. ${ }^{49}$ But if there were an excess of fiduciary coins in circulation (that is, if they exceeded the small-change needs), the market reacted first by removing the top coin from circulation (the grosso) and hoarding or exporting it. The next step was to demand more pennies per grosso. This market value might end up becoming the legal value without the penny's ceasing to be a fiduciary currency. ${ }^{50}$

From around the mid-13th century, fiduciary currency was essential to the good functioning of the medieval economy. It was the most widely used currency and had the highest velocity of circulation: the lower classes did not have another money and the rest of the population would also turn to it for small transactions or collection of income and taxes. As Sargent and Velde have said,

46 The penny was not a partial fiduciary money until after the introduction of the grossi, when the sum of pennies began to contain rather less silver than the corresponding grosso.

47 Especially in France during the Hundred Years War, but it was a temporary expedient, motivated by the need to collect money for the war.

48 In countries where the issuing authorities did not abuse seigniorage (such as England) or which had a less developed urban economy, fiduciary money was rare or unknown in the Middle Ages.

49 This explains why the circulation of local fiduciary coins was often accompanied by the introduction of foreign coins also accepted at a value greater than the metal they contained, as happened in England with the Venetian soldini, which were accepted as halfpennies ("galley half-pence") although they contained 20 per cent less silver than was theoretically requisite; Day, "Outline of money", p. 16.

50 That is, more than 12 pennies (or the corresponding number in the local monetary system) per grosso: Cipolla, "The big problem", pp. 30-31; as a general rule, the new market value did not equalize the silver contained in the corresponding grosso. 
"small coins can be used for large purchases but large coins cannot be used for small purchases". ${ }^{51}$ However, its importance lay particularly in the fact that real currency by itself would not have been able to meet demand for means of payment.

\section{Account Money}

As stated in the introduction, account money is a unit of value without physical support, which is helpful for counting and quoting but not for paying, since it is intangible ("ghost money"). ${ }^{52}$ Its advantage lies in the fact that it represents a relatively stable monetary value as opposed to the multiplication and variation of real coins. Account money is practically nonexistent in modern times, but it was very important between the Middle Ages and the 18 th century ${ }^{53}$ and did not disappear entirely until the middle of the 19th century. ${ }^{54}$

In the Middle Ages there were three forms of account money. The first is defined by the amount of silver or gold contained in an earlier coin that had left circulation, but that persisted as a unit of value. John Day called this "fossil money". 55 The second was based on the noble metal content of a coin in circulation; the metallic content was variable, but account money remained part of a system of a pound of 20 shillings and a shilling of 12 pennies. Changes to the real money had an effect on corresponding monies of account, since the relationship between them was fixed; it is therefore called "link money". ${ }^{66}$ The third type of money of account was the equivalent in silver of the value of a gold coin; the account pound took as 240 pennies the value in silver of the gold coin. The gold coin did not change, but its value fluctuated in relation to the

\footnotetext{
51 Sargent and Velde, Big Problem, p. 146.

$5^{2}$ On money of account, the most important works are: Van Werveke, "Monnaie de compte et monnaie réelle"; Bloch, Esquisse d'une histoire monétaire, pp. 39-49; Cipolla, "Ghost money", pp. 38-39; Lane, "La mobilità e l'utilità delle monete di conto", pp. 9-31; Spufford. Money and its Use, pp. 411-12; and L. Fantacci, "Teoria della moneta immaginaria".

53 The abandonment of money of account was due in particular to the simplification of monetary systems in each country, and to the exclusion of foreign coins from circulation.

54 After the introduction of the euro, many people continued calculating for some time in the suppressed local currency, which therefore functioned as account money. More formal was the ECU, which quoted the different European currencies prior to the euro. Constant moneys used to calculate economic series (dollars of 1971, for example) are also current account moneys.

55 Day, "Problem of the standard", p. 72.

56 Munro, "Monnayage, monnaies de compte", pp. 264-65.
} 
corresponding account money, its equivalent in shillings or pennies of account rising or falling proportionately. ${ }^{57}$

The difference between fossil, link, and bimetallic moneys of account is that the first is a fixed value and the others variable. Some authors also consider as account money the Carolingian system, but it is really only a current coin and its multiples, ${ }^{58}$ just as at present we use thousands or millions for counting large quantities. In other words, the Carolingian system was adopted as account money, but it was not in itself a system of account.

Money of account arose due to the coexistence in one place of pennies of different value. When the local currency with more value stops circulating, it becomes fossilized as account money and switches to rating other currencies in the market. ${ }^{59}$ In various places, more stable foreign currencies were also used as money of account, functioning first as link money and later becoming fossil money when they disappeared from circulation. ${ }^{60}$

Currency of account expanded in the 11th century and more forcefully from the 13th due to the multiplication of circulating coins. Beginning in the 13th century, account moneys expanded because people were used to counting according to the Carolingian system, but had to accommodate the addition of new coins, whether grossi or gold pieces. They had to start thinking of an abstract account money that could express value in pounds and subdivisions of shillings and pennies, thus giving rise to two pennies with different values: the real penny, variable, and the account penny, set as the 240th part of the corresponding pound. If the real coin was in gold, the account pound translated its value in silver. The situation could become even more complicated: a certain value of the real currency could fossilize and become an account money detached from the evolution of the respective coin. In this way, alongside the account money based on the Carolingian system, there appeared account florins, ducats, etc. ${ }^{61}$ Cipolla has described this evolution in Milan with great

57 Van Werveke, "Monnaie de compte et monnaie réelle", p. 9; Lane, "La mobilità e l'utilità delle monete di conto", pp. 13-16. Both authors agree on the first two types. Lane adds the third type, based on the bimetallic relationship of gold and silver. Werveke deals with another form of account money, which has no relationship to any real currency ("imaginary currency"), but only to deny its existence.

58 Bloch, Esquisse d'une histoire monétaire, p. 43.

59 As Bloch states in Esquisse d'une histoire monétaire, p. 38, all currency tended to become account money.

6o In Catalonia, for example, the mancus was a real currency at the end of the 1oth century and much of the 11th, but soon it was also used as account money: Bonnassie, La Catalogne du milieu du Xe à la fin du XIe siècle, vol. 1, pp. 372-84, vol. 2, pp. 920-24; and Balaguer, "Parias and myth of the Mancus".

61 Lane, "La mobilità e l'utilità delle monete di conto", p. 20. 
clarity: the florin was rated at 120 imperial pennies in 1252 , climbed to 384 pennies in 1340, and maintained this rate during the second half of the 14th century, to the point that it became customary to divide it into 12 shillings of $3^{2}$ pennies (384 pennies). In 1445 the gold florin climbed to 786 pennies, two account florins. ${ }^{62}$

In cities such as Florence and Venice the creation of a new real coin was accompanied by the creation of a separate and corresponding account pound (bimetallic account money) rated in silver currency and divided into 20 shillings and 240 pennies. ${ }^{63}$ Thus in both cities existed besides the lira di piccoli ${ }^{64}$ (pound of pennies) the lira di grossi, which was equivalent to 240 grossi; the latter tended to be rated as equivalent to progressively more pennies, while the lira di piccoli remained fixed at 240. In both cities other account moneys arose. In Florence, from 1269 the lira affiorino was the fossilization of the latest value (29 shillings) of the pound or grosso of silver, which had ceased to circulate. ${ }^{65}$ The 15th century saw the fiorino largo di grossi (greater florin in silver grossi), account money of the fiorino largo, coined from 1422 with the same gold content as the Venetian ducat; and the fiorino a suggello (sealed florin) account money equivalent to the silver standard value of the florin of the same name. ${ }^{66}$ From 1471, the fiorino largo was joined by the fiorino largo di oro in oro. The difference between the two was that the first went on being an account bimetallic money whose penny was the 240th part of the (variable) value in silver of the golden florin, while the penny of the second was worth merely the 240th part of the stable golden florin (see Figure 2.3). ${ }^{67}$

In Venice, in 1472, there was a reversal of roles. The dogo Nicolò Tron commanded the minting of a pound of silver (lira Tron), which meant the translation into real currency of the pound of account (240 pennies). ${ }^{68}$ In addition to the pounds of piccoli and of grossi already mentioned, Venice had a distinct

62 Cipolla, “Ghost moneys", pp. 46-47.

63 "Each time the authorites set a legal tender value for a gold florin, a ghost florin of the same name emerged as a silver based unit of account": Sargent and Velde, Big Problem, p. 147 .

64 In Venice, piccioli.

65 Spufford, Handbook of Medieval Exchange, p. 34.

66 Actually the fiorino a suggello represented the medium value of a specific number of gold florins enclosed in a bag sealed by a city officer, who ensured that they met the minimum legal content of gold. Such bags were accepted in the market as real currency: Day, "The problem of the standard", p. 72; and Sargent and Velde, Big Problem, p. 149.

67 Spufford, Handbook of Medieval Exchange, p. 28.

68 The characteristics of each one of these account moneys can be seen in Day, "Problem of the standard", pp. 65-74, and Sargent and Velde, Big Problem, pp. 82-83 and 149-85. 
PENNIES FOR FLORINS OF ACCOUNT

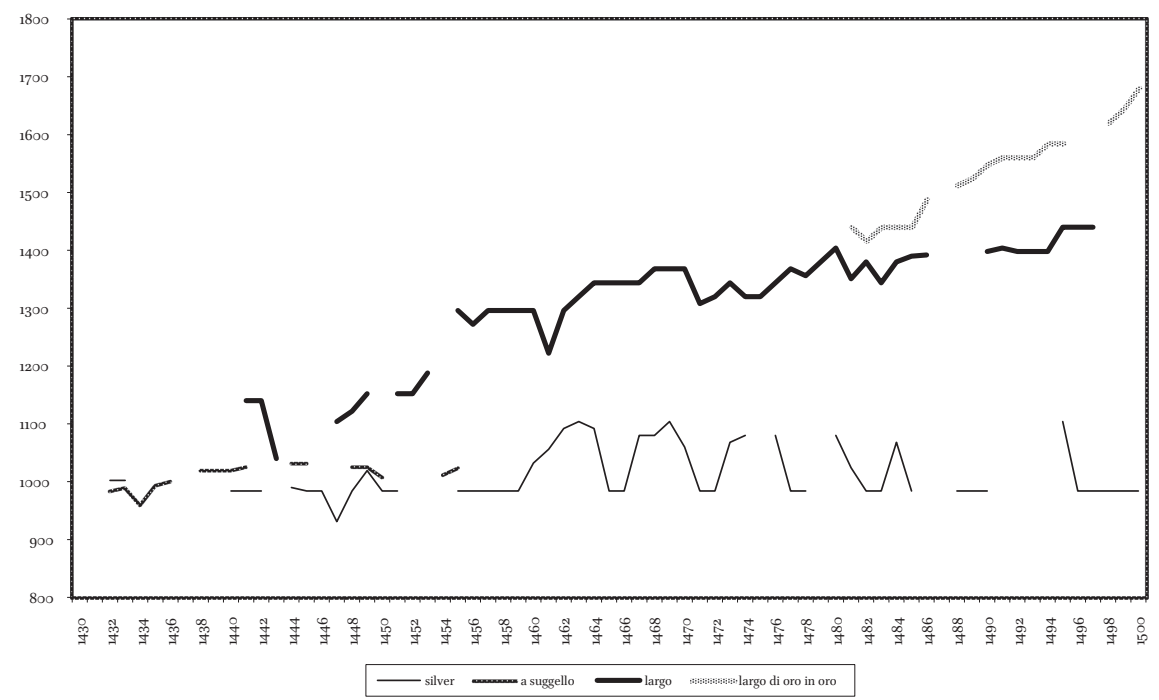

FIGURE 2.3 Number of pennies in different florins of account at Florence 1430-15OO. ADAPTED BY THE AUTHOR FROM SPUFFORD, HANDBOOK OF MEDIEVAL EXCHANGE, PP. 1-33. THE SILVER FLORIN REFLECTS THE OFFICIAL VALUE, THE OTHERS, MARKET VALUES. ONLY THE FIRST KNOWN VALUE OF EACH YEAR HAS BEEN USED.

lira a grossi, the penny of which represented the 12th part of the value of a grosso. ${ }^{69}$ The coining of the gold ducat (1285) had provoked a split of the lira di grossi: the lira di grossi a moneta continued to be linked to the silver coin, while the lira di grossi a oro (1328) was tied to the value of the ducat and so increased in value with regard to silver coins. Although the ducat was first fixed at 18 grossi, after 1296 it was valued at 24 , so that a lira di grossi a oro came to be worth 10 ducats. ${ }^{70}$

The most important use of account money was as written money. In fact, its generalization runs parallel with the expansion of commercial accounting. The passage of a notebook of annotation of debts and payments to a true system of account required the use of a single currency in the operations (sums, balances, credits, etc.). The coins actually received were listed in the body of the register, but were translated into account money as totals in the credit and

69 Spufford, Handbook of Medieval Exchange, pp. 91-92.

70 Lane, "La mobilità e l'utilità delle monete di conto", p. 16. 
debit columns. ${ }^{71}$ Rents and debts were also stipulated in written currency, more flexible and more secure than the circulating real coins; nevertheless, holders of written currency, like all creditors, were handicapped by the debasement of the penny and therefore of account money. Whatever currency was actually delivered, the deposit or debt was registered in account money; therefore, in case of debasement, the payment required an amount of real currency lower in value than the sum received. In some cases, pressure by creditors succeeded in modifying the bank registries to reduce the loss: ${ }^{72}$ it was safer to note debts, income, and accounting in real currency, or in account money not based on the penny. Although there are some examples of this, account money was almost always the norm. ${ }^{73}$

Although by definition account money was not a means of payment, this rule has an important exception: payments by transfer (between accounts of the same bank or those of different banks), which were carried out without intervention of currency. ${ }^{74}$ Obviously, any transfer came from a deposit in currency and had as a last resort a withdrawal in cash, but paying in account money allowed an individual or firm to meet one or successive debts without the coins having to leave the coffers of the bank. It was therefore a considerable increase of the availability of means of payment, or more technically amounted to an increase of the velocity of circulation of the currency for the benefit of economic activity.

\section{Conclusions}

Long-term examination of medieval money emphasizes two basic and crucial constants. In the first place, the demand for currency created its own challenges. The scarcity of cash during the barbarian centuries was counterbalanced by payments in kind, in any form. The growing demand of means of payment in the 9 th to 12 th centuries was settled generally with the debasement of the penny. The needs of urban manufacturing and large-scale trade gave rise to full silver coins and to gold coins, but also needed the support of fiduciary and written account money.

\footnotetext{
71 Zerbi, Moneta effetiva e moneta di conto.

72 In Barcelona, in 1457, for instance, among strong social tensions: Feliu, "Finances, currency and taxation", pp. 33-34.

73 Day, "Problem of the standard", p. 65; and Sargent and Velde, Big Problem, pp. 76-78.

74 Usher, Early History of Deposit Banking, p. 201; and Cipolla, "Ghost money", pp. 50-51
} 
Secondly, "money matters". Monetary changes are passive neither economically nor socially; coin behaves as a living being. ${ }^{75}$ The changes in the value of currencies tended to favour debtors, among them those subject to the payment of fixed sums, and to be harmful to creditors. ${ }^{76}$ The currency available to different groups indicates their economic power and social class; in the late Middle Ages, a few had gold coins, but the greater part of the population had access only to the petty money, subject to a constant debasement that converted it into black coin, the coin of the poor. With the passage of time, the increase in the value of gold compared to silver, and the debasement of the penny with respect to the grosso and still more to gold, made the rich richer and the poor poorer. Certainly, the authorities did what they could to prevent or slow this process, but the trend was irreversible. ${ }^{77}$

Altogether this leads us to a somewhat pessimistic conclusion: as Michel Dhénin says, currency is made in such a way that there is not a good system, but an evil compromise: the aspects that favour economic activity are at the same time socially discriminatory. ${ }^{78}$

\section{Bibliography}

\section{Primary Sources}

Abadal i de Vinyals, R., Catalunya Carolíngia, Vol. 3: Els comtats de Pallars i Ribagorça, Barcelona, 1955 .

Magnou-Nortier, E., \& Magnou, A.M. (eds.), Recueil des Chartes de l'Abbaye de la Grasse, 2 vols., París, 1996.

\section{Secondary Literature}

Balaguer, A.M., "Parias and myth of the Mancus", in M.G. Marques \& D.M. Metcalf (eds.), Problems of Medieval Coinage in the Iberian Area, Santarém, 1988, 499-545.

Bisson, T.N., Conservation of Coinage: Monetary Exploitation and Its Restraint in France, Catalonia, and Aragon, C.A.D. 1000-1225, Oxford, 1979.

\footnotetext{
75 Munro, "Introduction", p. 1; and Dhénin, "L'Or, l'argent, le bronze", p. 839. See also chapter 3, this volume.

76 An important part of agricultural growth was undoubtedly owed to the decrease in value of rents and dues; hence the nobility and the Church would always be opposed to the depreciation of the currency.

77 Cipolla, "The big problem", pp. 33-35.

78 Dhénin, "L'Or, l'argent, le bronze", p. 838.
} 
Bloch, M., "Economie nature ou économie argent: un pseudo-dilemme", Annales d'histoire économique et social 11 (1939), 7-16; repr. in M. Bloch (ed.), Mélanges historiques vol. 2, París, 1963, 869-77; and as "Natural economy and money economy: a pseudodilemma", in M. Bloch (ed.), Land and Work in Medieval Europe, trans. J.E. Anderson, London, 1967, 230-43.

Bloch, M., Esquisse d'une histoire monétaire de l'Europe, Paris, 1954.

Bonnassie, P., La Catalogne du milieu du Xe à la fin du XIe siècle, croissance et mutations d'une société, 2 vols., Toulouse, $1975^{-76}$.

Cipolla, C.M., "The big problem of the petty coins", in Cipolla, Money, Prices and Civilization in the Mediterranean World, 1956, 27-37.

Cipolla, C.M., "Currency depreciation in medieval Europe", Economic History Review 15:3 (1963), 413-22; repr. in S. Thrupp (ed.), Change in Medieval Society: Europe North of the Alps, 1050-1500, New York, 1964, 227-36.

Cipolla, C.M., "Ghost moneys", in Cipolla, Money, Prices and Civilisation in the Mediterranean World, 1956, 38-51.

Cipolla, C.M., Money, Prices and Civilisation in the Mediterranean World, Princeton, NJ, 1956.

Cipolla, C.M., "Primitive money in primitive Europe", in Cipolla, Money, Prices and Civilisation in the Mediterranean World, 1956, 3-12.

Davies, W., "Sale, price and valuation in Galicia and Castile-Leon in the tenth century", Early Medieval Europe 11 (2002), 149-74.

Day, J., "Introduction”, in J. Day (ed.), Études d'histoire monétaire, XIIe-XIXe siècles, Lille, 1984; repr. as "An outline of money from the Middle Ages to the Industrial Revolution" in J. Day, Money and Finance in the Age of Merchant Capitalism, Oxford, 1999, 1-58.

Day, J., "The problem of the standard in pre-industrial Europe", in I. Zilli (ed.), Fra spacio e tempo. Studi in onore di Luigi De Rosa, I. Dal Medioevo al Seicento, Naples, 1995, 59-109; repr. in J. Day, Money and Finance in the Age of Merchant Capitalism, Oxford, 1999, 59-109.

Day, W.R. Jr., "The monetary reforms of Charlemagne and the circulation of money in early medieval Campania", Early Medieval Europe 6 (1997), 25-45.

Dhénin, M., "L'Or, l'argent, le bronze, métaux monétaires", in Mercati e mercanti nell'Alto Medioevo. L'area euro-asiatica e l'area mediterranea. Settimana di Studio del Centro Italiano di Studi sull'Alto Medioevo, XL. 23-29 aprile 1992, Spoleto, 1993, 827-46.

Duplessy, J., "La circulation des monnaies arabes en Europe Occidentale du VIIIe au XIIIe siècle", Revue Numismatique 18 (1956), 101-59.

Einzig, P., Primitive Money in Its Ethnological and Economic Aspects, London, 1949.

Fantacci, L., "Teoria della moneta immaginaria nel tempo da Carlomagno a Richard Nixon", Rivista di Storia Economica 18 (2002), 301-25.

Feliu, G., "Finances, currency and taxation in the 14th and 15th centuries", Catalan Historical Review 9 (2016), 25-44. 
Fournial, E., Histoire monétaire de l'occident médiéval, Paris, 1970.

Gautier-Dalché, J., "L'histoire monétaire de l'Espagne septentrionale et centrale du IXe au XIIe siècles", Anuario de Estudios Medievales 6 (1969), 43-96.

Graeber, D., Debt: The First 5, ooo Years, New York, 2011.

Grierson, P., "Carolingian Europe and the Arabs: the myth of the mancus", Revue Belge de philologie et d'histoire 32 (1954), 1059-74; repr. in P. Grierson, Dark Age Numismatics, London, 1979 .

Jarrett, J., "Currency change in pre-millennial Catalonia: counts and economics", $\mathrm{Nu}$ mismatic Chronicle 169 (2009), 217-43.

Lane, F., "La mobilità e l'utilità delle monete di conto", Rivista di storia economica 1 (1984), 9-31.

Lopez, R.S., "Back to gold, 1252", Economic History Review 9 (1956), 219-4O; repr. in R.S. Lopez, The Shape of Medieval Monetary History, London, 1986.

Lopez, R.S., "Settecento anni fa: il ritorno all'oro nell'occidente duecentesco", Rivista Storica Italiana 65 (1953), 19-55 and 161-98; repr. in R.S. Lopez, The Shape of Medieval Monetary History, London, 1986.

Miskimin, N.B., "Two reforms of Charlemagne?: weights and measures in the Middle Ages", Economic History Review 20 (1967), 35-52.

Munro, J.H.A., "Introduction", in J.H.A. Munro (ed.), Money in the Pre-Industrial World: Bullion Debasements and Coin Substitutes, London, 2012.

Munro, J.H.A., "Monnayage, monnaies de compte et mutations monétaires au Brabant à la fin du Moyen Age", in J. Day (ed.), Études d'Histoire monétaire XIIe-XIXe siècles, Lille, 1984, 283-94; repr. in J.H.A. Munro, Bullion Flows and Monetary Policies in England and the Low Countries, 1250-1500, London, 1992.

Munro, J.H.A., "The technology and economics of coinage debasement in medieval and early modern Europe with special reference to the Low Countries and England", in J.H.A. Munro (ed.), Money in the Pre-Industrial World: Bullion Debasements and Coin Substitutes, London, 2012, 15-32.

Naismith, R., "The social significance of monetization in the early Middle Ages", Past \& Present 223 (2014), 3-39.

Sánchez-Albornoz, C. Estampas de la vida en León durante el siglo X, León, 1985 (1926).

Sargent, T.J., and Velde, F.R., The Big Problem of Small Change, Princeton, NJ, 2002.

Spufford, P., Handbook of Medieval Exchange, London, 1986.

Spufford, P., "Monetary practice and monetary theory in Europe (11th-15th centuries)", in XXVI Semana de Estudios Medievales. Estella-Lizarra 19-23 julio 1999. Moneda y monedas en la Europa Medieval (siglos XII-XV), Pamplona, 200o, 53-86.

Spufford, P., Money and Its Use in Medieval Europe, Cambridge, 1988.

Sussmann, N., "Debasement, royal revenues and inflation in France during the Hundred Years' War, 1415-1422", Journal of Economic History 53 (1993), 44-70. 
Usher, A.P., The Early History of Deposit Banking in Mediterranean Europe, Cambridge, Mass., 1943.

Van Werveke, H., "Monnaie de compte et monnaie réelle", Revue Belge de Philologie et Histoire 3 (1934), 123-52.

Van Werveke, H., "Monnaie, lingots ou marchandises? Les instruments d'échange aux XI et XII siècles", Annales d'Histoire Économique et Sociale 4 (1932), 452-68.

Zerbi, T. Moneta effetiva e moneta di conto nelle fonti contabili di Storia Economica, Milan, 1955 . 